\title{
Carcinosarcoma of the bladder: case report and review of the literature
}

\author{
Arda Akoluk, MD, ${ }^{*}$ Yagil Barazani, MD; ${ }^{\dagger}$ Denisa Slova, $M D_{,}^{\ddagger}$ Sovrin Shah, ${ }^{\dagger}$ Basir Tareen, $M D^{\dagger}$ \\ ${ }^{*} Y$ editepe University School of Medicine, Istanbul,Turkey, `Sol and Margaret Berger Department of Urology, Beth Israel Medical Center, New York, NY; ${ }^{\ddagger}$ Department of Pathology, Beth Israel Medical \\ Center, New York, NY
}

Cite as: Can Urol Assoc J 2011;5(4):e69-e73; D01:10.5489/cuaj.10161

\section{Abstract}

Primary osteosarcomas of the bladder account for about $0.04 \%$ of bladder neoplasms. Most of the patients in the literature expired within 6 months and, in almost all of the cases in the literature, radical cystectomy with postoperative chemotherapy was the treatment choice. A 79-year-old gentleman presented with gross hematuria. Cystoscopy demonstrated a 2- to 3-cm tumour along the lateral wall of the bladder. The tumour was resected incompletely via initial transurethral resection of bladder tumour (TURBT), and a second TURBT was subsequently performed to fully resect the residual mass. Surgical pathology from these 2 resections revealed osteosarcoma with invasion into the muscularis propria. A cystoprostatectomy was performed and final pathologic specimen revealed high-grade CIS without evidence of residual osteosarcoma. Postoperatively, the patient did not receive chemotherapy or radiation and currently remains disease-free 2 years post-radical cystectomy. Only 33 well-documented cases of primary osteosarcoma of the bladder have been reported to date. However, there are only 3 cases in which TURBT resulted in complete resection.

\section{Introduction}

The presence of a malignant tumour of bone tissue in the bladder is extremely rare, with malignant mesenchmal tumours comprising less than $0.04 \%$ of bladder malignancies. ${ }^{1}$ About 35 well-documented cases having been reported in the English literature to date. ${ }^{1-15,16-29}$ The presence of both a carcinomatous and sarcomatous component in the bladder is termed a carcinosarcoma. This case is unique in that a transurethral resection of bladder tumour (TURBT) resulted in complete resection of the sarcoma component of the bladder, with an ultimate radical cystoprostatectomy specimen showing no osteosarcoma, but only residual carcinoma in situ (CIS).

\section{Case report}

A 79-year-old male was referred to our institution in August 2008 with a 2-month history of gross hematuria. A computed tomography (CT) scan of the abdomen and pelvis without intravenous (IV) contrast, performed at an outside institution 1 month prior, revealed a 4 -cm calcification in the left lateral wall of the bladder (Fig. 1, Fig. 2. Fig. 3). Past medical history was remarkable for diabetes and a 20-pack/year smoking history. Physical exam was unremarkable. An office cystoscopy revealed a 2- to 3-cm tumour on the left lateral wall of the bladder (Fig. 4). A CT with IV contrast revealed a polyploid mass arising in the posterolateral aspect of the urinary bladder without pelvic or retroperitoneal lymphadenopathy (Fig. 2). A TURBT was performed in September 2008, which revealed a large sessile tumour on the left lateral wall of the bladder, cephalad and lateral to the left ureteral orifice. The tumour was difficult to cut with electrocautery. Initial pathology revealed an osteosarcoma which stained positive for cytokeratin AE1-3. A second TURBT demonstrated a poorly differentiated malignant neoplasm with features compatible with carsinosarcoma with the previously seen osteosarcoma and urothelial CIS.

Muscularis propria was present in the specimen and found to be free of tumour invasion. While the foci of tumour cell nesting suggestive of epithelial differentiation were seen, there were widespread highly atypical stromal cells associated with osteoid-like material consistent with carcinosarcoma predominantly, osteosarcoma with a small area of CIS (Fig. 5)

Staging studies, including a total body bone scan and CT of the chest, were negative for metastatic disease. A radical cystoprostatectomy, extended pelvic lymph node dissection and ileal conduit urinary diversion was performed. Pathology demonstrated only CIS without evidence of osteosarcoma of the bladder and absence of lymphovascular invasion. Seminal vesicles were negative for malignancy and all lymph nodes were negative (Fig. 6). 


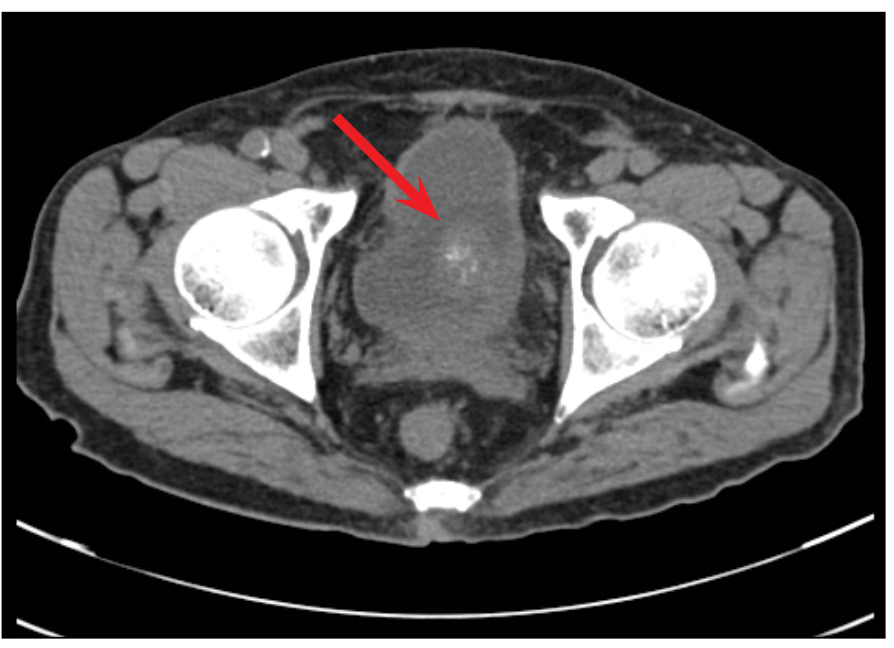

Fig. 1. Noncontrast computed tomography showing the mass (shown by the arrow).

Currently, the patient is alive and disease-free 2 years postoperatively, as indicated by surveillance CTs and magnetic resonance imaging of the chest, abdomen and pelvis at 6-month intervals.

\section{Discussion}

Sarcomas of the bladder are rare, with the most common histology in adults and children being leiomyosarcomas and rhabdomyosarcomas, respectively. ${ }^{11-15}$ Carcinosarcomas with osteogenic components are extremely uncommon, with about 40 cases reported in the literature. ${ }^{1-15,16-23}$

In 1856, Ordonez recorded the first report of a malignant bladder tumour containing elements of cartilage or bone. ${ }^{12}$ This first case report gives few clinical details and deals chiefly with the histologic structure, which today would be classified as a chondrosarcoma. The second case was reported by Shattock in 1887, who reported a tumour in a 55 -yearold male located in the region of the trigone near the right ureteral orifice, and productive of hematuria and dysuria for 4 years. ${ }^{13}$ On surgical excision, the tumour was described as papillary in form and covered by a mucous membrane. Histologically, it was described as being composed of cartilage. This patient died 9 months postoperatively and, at autopsy, was noted to have a large soft growth 2 inches in diameter encroaching on the bladder from the base. The third reported case was from Beneke in 1899..$^{14-24,30,31}$ This case was different from the 2 prior cases in that it consisted of both bone and cartilage. About 100 years later, a case was reported and the literature was reviewed for the first time in 1943 by Crane and Tremblay. ${ }^{11}$ In their article, they managed to find 8 osteo- or chondrosarcoma cases by looking at more than 200 reported cases of carsinosarcomas of the bladder.

Since their earliest description in the literature, the origin of such tumours remains unclear. It was suggested that

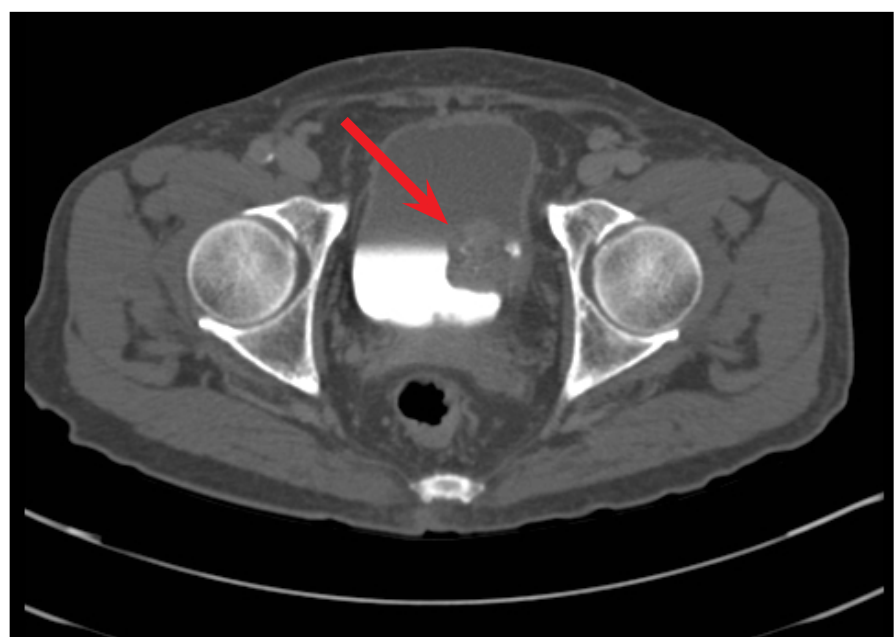

Fig. 2. Delayed contrased CT showing a $2-3 \mathrm{~cm}$ mass on the lateral wall of the bladder (shown by the arrow).

extraskeletal osteosarcomas might represent malignant growth of a single component in a teratoma. ${ }^{23}$ Chitiyo listed 4 possible methods of histogenesis: (1) metaplasia of the bladder epithelium; (2) stromal metaplasia; (3) transfer of osteoblasts via blood stream; or (4) the development of osteoblasts from immature mesenchymal tissue derived from the Wolfian body from which the trigone develops. ${ }^{6}$ Kikuchi and colleagues suggested that the frequent location of these tumours in the trigone is evidence of an origin from the Wolfian body..$^{19}$ In our case, the tumour was located near the trigone and can supports Kikuchi's hypothesis.

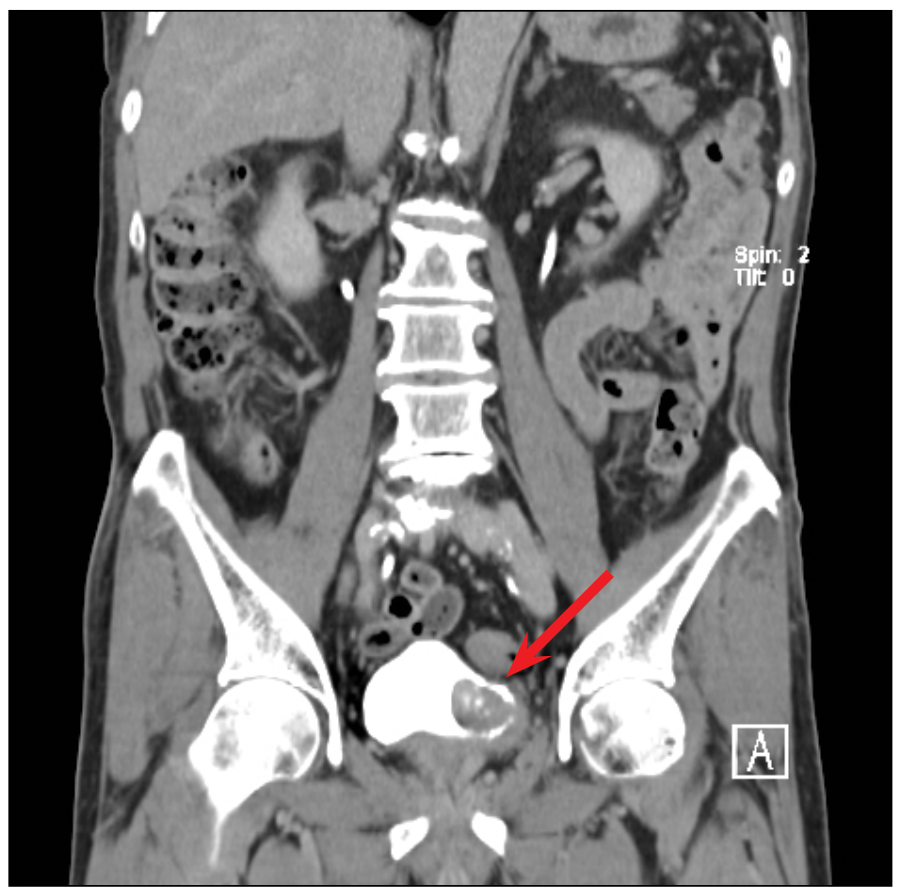

Fig. 3. Delayed contrasted coronal computed tomography showing a $2-3 \mathrm{~cm}$ tumour on the lateral wall of the bladder(shown by the arrow). 


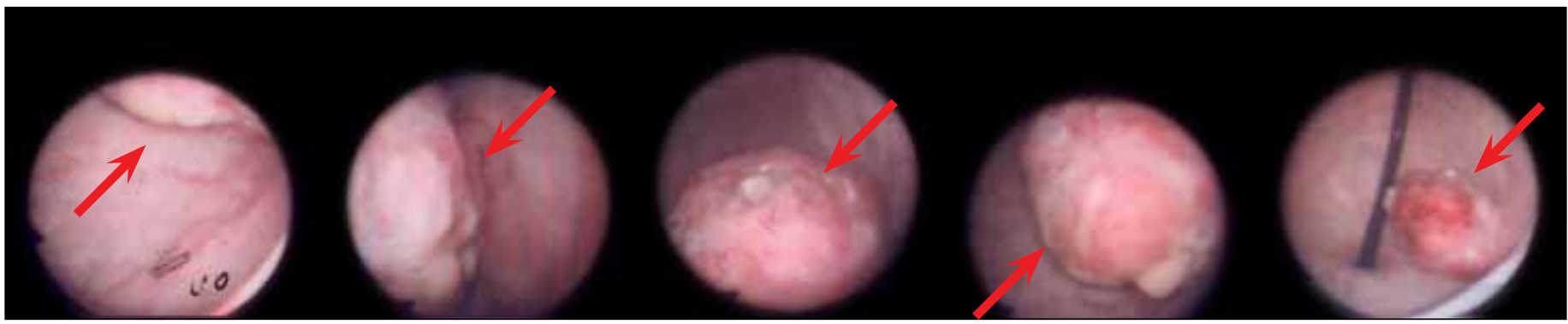

Fig. 4. Cystoscopy images showing a large tumour on the right lateral wall of the bladder away from the ureteral orifice.

Carcinosarcomas with osteogenic components are reported to occur in both genders, with a male to female ratio of $4: 1$. Reported patient ages at diagnosis range from 24 to 86 , with a mean age of 62 years. Nodal and distant organ metastases at diagnosis are common and $70 \%$ of patients died of cancer at 1 to 48 months (mean 17 months). Patients most often present with symptoms similar to those of a more typical urothelial bladder malignancy, including hematuria, dysuria and urinary frequency. Most cases present in association with transitional cell carcinoma. The most common heterologous element is osteosarcoma followed by chondrosarcoma, rhabdomyosarcoma, leiomyosarcoma, liposarcoma angiosarcoma or multiple types of heterologous differentiation. By immunohistochemistry, epithelial elements react with cytokeratins, whereas stromal elements react with vimentin or specific markers corresponding to the mesenchymal differentiation. The sarcomatoid phenotype retains the epithelial nature of the cells by immunohistochemistry or electronmicroscopy. Recent molecular studies, strongly argue for a monoclonal origin of both components. The cytological atypia of sarcomatoid carcinoma excludes non-neoplastic lesions, such as the postoperative spindle

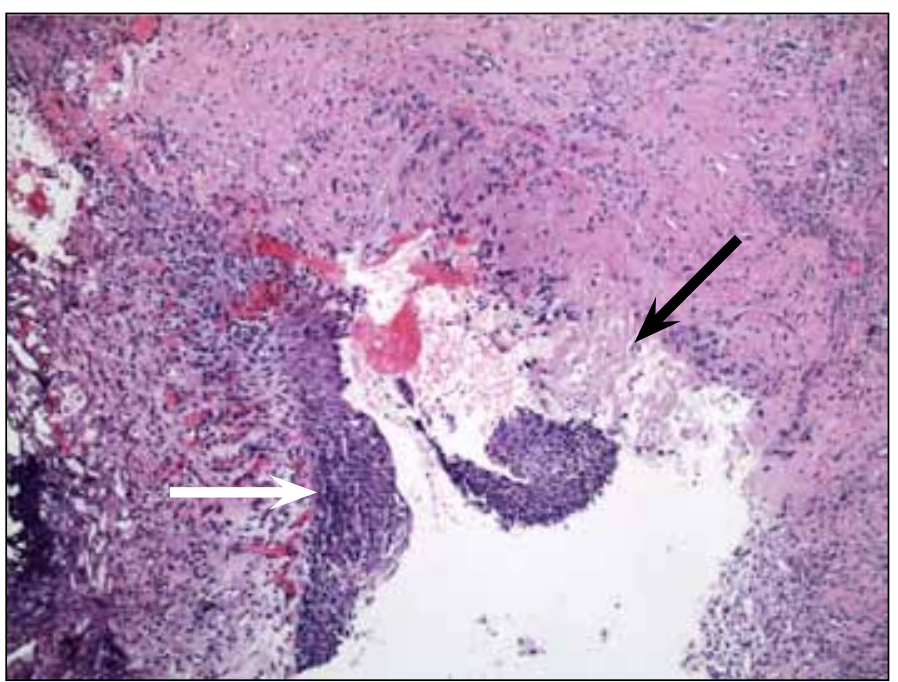

Fig. 5. Low power view showing the oseteosarcoma (black arrow) adjacent to a carcinoma in situ component (white arrow). There is loss of polarity but overall the architecture is still preserved in the in situ component cell nodule and inflammatory pseudotumour. Sarcomatoid carcinoma should be distinguished from the rare carcinoma with metaplastic, benign-appearing bone or cartilage in the stroma or those showing other pseudosarcomatous stromal reactions.

Currently, the mainstay of treatment for osteosarcomas of the bladder remains radical cystectomy in combination with radiation or chemotherapy, 30,31 though the efficacy of external beam radiation or chemotherapy in treating these rare sarcomas remains unproven.

There are several reports of cases in which bladder sparing options were used with or without chemotherapy/radiation (Table 1). Regardless of treatment type, most patients with osteosarcoma of the bladder expired early in the course of their disease. However, 3 reports show a 2- to 3-year survival with either TURBT or partial cystectomy. A TURBT offers the advantages of bladder preservation, short hospital course and minimal blood loss and other complications associated with radical extirpation. However, conservative treatment options have several limitations. First, the tumour may be composed of calcified tissue that proves difficult to cauterize or cut. Local reccurences are very common and complete resection may be difficult. Moreover, osteosarcomas of the

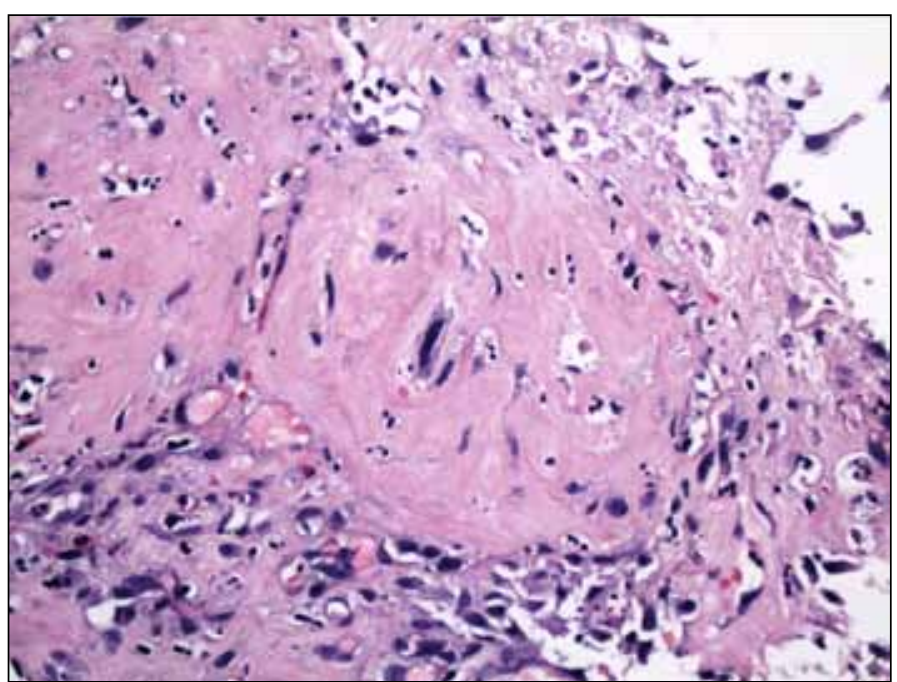

Fig. 6. High power view of osteosarcoma showing osteoid produced by highly cytologically malignant cells. 
Akoluk et al.

Table 1. Case reports in the literature in which conservative treatment options were used

\begin{tabular}{|c|c|c|c|c|c|c|}
\hline Authors (year) & Sympoms & Age/sex & Treatment & Tumour size & Tumour location & Outcome \\
\hline Nourse $(1957)^{3}$ & $\begin{array}{l}\text { Dysuria and } \\
\text { frequency }\end{array}$ & $44 / \mathrm{M}$ & TURBT & $8 \times 8 \times 6 \mathrm{~cm}^{3}$ & $\begin{array}{l}\text { Posterior wall } \\
\text { dome }\end{array}$ & $\begin{array}{c}\text { Suprapubic } \\
\text { fistula in } 3 \text { weeks, } \\
\text { failed to close, } \\
\text { expired } 49 \text { days } \\
\text { postop }\end{array}$ \\
\hline Pang $(1958)^{4}$ & $\begin{array}{l}\text { Previous tumour } \\
\text { resection and } \\
\text { ulceration }\end{array}$ & $60 / F$ & $\begin{array}{c}\text { Partial } \\
\text { cystectomy }\end{array}$ & $4 \times 3 \times 3 \mathrm{~cm}^{3}$ & $\mathrm{~N} / \mathrm{A}$ & $\mathrm{N} / \mathrm{A}$ \\
\hline $\begin{array}{l}\text { Nicolai \& Spjut } \\
(1959)^{5}\end{array}$ & $\begin{array}{l}\text { Hematuria, } \\
\text { dysuria and } \\
\text { chronic UTI }\end{array}$ & $66 / \mathrm{M}$ & $\begin{array}{c}\text { Partial } \\
\text { cystectomy }\end{array}$ & $5 \mathrm{~cm}$ & Left lateral wall & $\begin{array}{l}\text { Expired within } \\
36 \text { hours from } \\
\text { cardiac and } \\
\text { pulmonary } \\
\text { complications } \\
\text { (autopsy showed } \\
\text { no tumour on the } \\
\text { bladder) }\end{array}$ \\
\hline Delides $(1972)^{16}$ & Hematuria & $65 / \mathrm{M}$ & TURBT & Small & $\mathrm{N} / \mathrm{A}$ & $\begin{array}{l}\text { NED } 3 \text { years } \\
\text { post-op }\end{array}$ \\
\hline $\begin{array}{l}\text { Narayama et al. } \\
(1978)^{7}\end{array}$ & $\mathrm{~N} / \mathrm{A}$ & $62 / \mathrm{M}$ & TURBT & N/A & N/A & $\begin{array}{c}\text { Tumour } \\
\text { reccurrence at } \\
2 \text { yrs }\end{array}$ \\
\hline $\begin{array}{l}\text { Young et al. } \\
(1987)^{15}\end{array}$ & Hematuria & $52 / \mathrm{M}$ & TURBT & $6 \times 5 \mathrm{~cm}$ polypoid & $\begin{array}{l}\text { Anterior bladder } \\
\text { wall }\end{array}$ & $\begin{array}{c}\text { Bladder } \\
\text { recurrence at } 21 \\
\text { months, treated } \\
\text { TURBT }\end{array}$ \\
\hline $\begin{array}{l}\text { Berenson at al. } \\
(1986)^{9}\end{array}$ & $\begin{array}{l}\text { Pelvic discomfort, } \\
\text { dysuria and } \\
\text { frequency }\end{array}$ & $49 / \mathrm{M}$ & $\begin{array}{c}\text { Left } \\
\text { hemicystectomy } \\
\text { and transuretero- } \\
\text { ureterostomy }\end{array}$ & $2-3 \mathrm{~cm}$ & Left bladder wall & $\begin{array}{c}\text { Bilateral } \\
\text { pulmonary } \\
\text { metastases and } \\
\text { recurred 6-9 } \\
\text { months with } \\
\text { poorly diff CA }\end{array}$ \\
\hline $\begin{array}{l}\text { Kato et al. } \\
(2000)^{21}\end{array}$ & $\begin{array}{l}\text { Hematuria, } \\
\text { frequency and } \\
\text { dysuria }\end{array}$ & $55 / \mathrm{M}$ & $\begin{array}{c}\text { Partial } \\
\text { cystectomy }\end{array}$ & $5 \times 5 \times 6 \mathrm{~cm}$ & $\begin{array}{l}\text { Right posterior } \\
\text { wall }\end{array}$ & $\begin{array}{l}\text { No evidence of } \\
\text { recurrence at } 36 \\
\text { months }\end{array}$ \\
\hline $\begin{array}{l}\text { Mohan et al. } \\
(2001)^{32}\end{array}$ & $\begin{array}{l}\text { Hematuria, } \\
\text { urinary } \\
\text { obstruction }\end{array}$ & N/A & $\begin{array}{c}\text { TURBT } \\
\text { and partial } \\
\text { cystecyomy }\end{array}$ & $\begin{array}{c}3.0 \times 2.5 \times 1.5 \\
(\text { grade } 3)\end{array}$ & N/A & $\begin{array}{c}\text { Metastasis } \\
\text { to colon } \\
\text { (laparatomy } \\
1 \text { year postop) } \\
\text { but recovered }\end{array}$ \\
\hline Our case & $\begin{array}{c}\text { Gross, painless } \\
\text { hematuria, } \\
\text { nocturia and } \\
\text { decrease in urine } \\
\text { flow }\end{array}$ & $80 / \mathrm{M}$ & $\begin{array}{l}\text { TURBT } \times \\
2, \text { radical } \\
\text { cystectomy }\end{array}$ & $2-3 \mathrm{~cm}$ & $\begin{array}{l}\text { Left lateral wall, } \\
\text { in trigone }\end{array}$ & $\begin{array}{l}\text { No chemo or } \\
\text { XRT, alive } 27 \\
\text { months postop }\end{array}$ \\
\hline
\end{tabular}

bladder may be accompanied by CIS or transitional cell carcinoma, and one has to consider these tumours when treating osteosarcoma. Nevertheless, a possible option for treating osteosarcoma of the bladder may be partial cystectomy or aggressive TURBT in the well-selected patient.

\section{Conclusion}

The recomended treatment choice for osteosarcoma of the bladder is complete surgical excision with cystoprostatectomy. The role of radiation therapy or chemotherapy is unclear. Several reported cases and our case may lend support for conservative treatment of carcinosarcoma with osteogenic components in the well-selected patient. 
Competıng interests: None declared.

This paper has been peer-reviewed.

\section{References}

1. Van Oyen PM, Bergmans G, Denyhs H, et al. Primary osteogenic sarcoma of the bladder. Acta Urol Belg 1987; $55: 380-2$.

2. Powers JH, Hawn CVZ, Carter RD. Osteogenic sarcoma and Transitional cell carcinoma occuring simultaneously in the urinary bladder: Report of a case. J Urol 1959;76:263-9.

3. Nourse MH. Primary osteogenic sarcoma of the bladder. J Urol 1957;77:634-8.

4. Pang LSC. Bony and cartilaginous tumours of the urinary bladder. J Patho Bacteriol 1958;76:357-7.

5. Nicolai CH, Spiut HJ. Primary osteogenic sarcoma of the bladder. J Urol 1959:82:497-9.

6. Chitiyo ME. Primary osteogenic sarcoma of the urinary bladder. J Pathol 1973;111:53-6.

7. Narayama AS, Leoning S, Weimar GW, et al. Sarcoma of the bladder and prostate. J Urol 1978;119:72-9.

8. Ferrie $B G$, Imrie JEA, Paterson PJ. Osteosarcoma of the bladder 27 years after local radiotherapy. J $R$ Soc Med 1984;77:962-3.

9. Berenson RJ, Flynn S, Freiha FS, et al. Primary osteogenic sarcoma of the bladder: Case report and review of the literature. Cancer 1986:57:350-5.

10. Sen SE, Malek RS, Farrow GM, et al. Sarcoma and carsinosarcoma of the bladder in adults. J Urol 1985; 133:29-30.

11. Crane AR, Tremblay RG. Primary osteogenic sarcoma of the bladder: Complete review of sarcomata of the bladder. Ann Surg 1943;118:887-908.

12. Ordonez MEC. $2^{\circ}$ transformation cartilagineuse de la vessie chez un vieillard. series $3 \mathrm{Gazz}$ Med Paris 1856;11:824.

13. Shattock SG. Chondrifying sarcoma removed, together with multiple papillomata, from the male urinary bladder. 1887;38:183-6.

14. Beneke R. Eim Fall von Osteoid-Chondrosarconm der Harnblase (mit Bemerkungen iiber Metaplasie). Virch Arch 1900;161;70-114.

15. Young RH, Rosenberg AE. Osteosarcoma of the bladder: report of a case and review of the literature. Cancer 1987;59:174-8.
16. Delides SG. Bone and cartilage in malignant tumours of the urinary bladder. Br J Urol 1972;44:571-81.

17. Papandreou C, Skopelitou A, Kappes G, et al. Primary osteosarcoma of the urinary bladder treated with external radiotherapy in a patient with a history of transitional cell carcinoma:a case report. J Med Case Reports 2010;4:70.

18. Okada E, Hasegawa Y, Takahashi K, et al. Primary osteosarcoma of the urinary bladder. Int Urol Nephrol 1997;29:437-40.

19. Kikuchi K, Nakamura K, Nakagima F, et al. An autopsy case of primary osteogenic sarcoma of the urinary bladder. Acta Pathol Jpn 1965;15:287-93.

20. Lamontagne AE Jr, $O^{\prime}$ Neill DG. Primary osteosarcoma of the bladder: a case report and review of the literature. Conn Med 1994;58:327.

21. Kato T, Kubota Y, Saitou M, et al. Osteosarcoma of the bladder successfully treated with partial cystectomy. J Urol 2000;163:548-9.

22. Kondo YA. A case of surgically removed osteogenic sarcoma of the urinary bladder. Gann 1960;51:286.

23. Fine G, Stout AP. Osteogenic sarcoma of the extraskeletal soft tissues. Cancer 1956:9:1027-43.

24. Beneke R. Osteoidchondrosarkom der Harnblase. Verhandl. d. deutsch. path. Gesellsch 1900;2:405-7.

25. Heisler G. Beitrige zur Lehre von den Harnblasengeschw6ilsten im Kindesalter. Inaug. Dissert. Basel; 1905.

26. Fischer WV. ther eim Osteoidchondrosarkom der Harnblase mit Metastasen. Arbeiten a. dem Gebiete der Path. Anat. u. Bakt. aus dem Path. AAnat. Inst. z. Tubingen; 1908;6:5911-60.

27. Ried K. Eim Fall vonl Chondromyxosarkom der Harnblase. Inaug. Dissert. K. B.Friedrich-Alexander. Univ. Erlangeni; 1913.

28. Wright-Smith RJ. Malignant teratoma (teratogenous sarcoma) of the urinary bladder. J Coll Surg Australasia 1929;2:271.

29. Droschl H. Uber Blasensarkome. (Osteoidsarkom der Harnblase). Deutsche Ztschr. f. Chir 1938;249:785-9.

30. Herr HW. Surgical factors in the treatment of superficial and invasive bladder cancer. Urol Clin North Am 2005;32:157-64.

31. Milosevic M. Radiotherapy for bladder cancer. Urology 2007;69(1 Suppl):80-92.

32. Mohan H, Ahal S, Nada R, et al. Osteosarcoma of the bladder-a case report. Indian J Pathol Microbiol 2001:44:451-2.

Correspondence: Dr. Basir Tareen, Physician-in-charge, Urologic Oncology, Department of Urology, Beth Israel Medical Center, 10 Union Square East, Suite 3A, New York, NY 10016; btareen@chpnet.org 